\title{
INVESTIMENTOS DA CHINA NO BRASIL, NA ÁFRICA DO SUL E NA ÍNDIA: ARRANJOS INSTITUCIONAIS, ATORES E IMPACTOS'
}

\author{
Ana Saggioro Garcia²
}

\begin{abstract}
O BRICS (Brasil, Rússia, Índia, China e África do Sul) constituiu um marco do início do século XXI e gerou expectativas de ser um polo alternativo à ordem mundial baseada nos Estados Unidos. Embora tenha construído diferentes espaços de cooperação e instituições comuns na última década, a relação entre os países do BRICS é assimétrica, principalmente em virtude do peso econômico da China. Este artigo tem por objetivo fornecer um panorama dos investimentos da China em três outros membros do BRICS: Brasil, África do Sul e Índia. Metodologicamente, evidenciamos as características mais relevantes dos investimentos chineses, observando os seguintes itens: principais empresas e bancos de investimento; volumes de investimento e principais setores; e participação do governo local e instituições parceiras privadas. Além disso, destacamos alguns programas e políticas públicas que facilitam o investimento chinês em cada um desses países. Por fim, verificamos a existência ou não de impactos sociais, ambientais e trabalhistas que possam estar envoltos nos projetos. Neste sentido, 0 artigo fornece aspectos relevantes que permitem identificar similaridades e diferenças nas relações econômicas de cada país com a China. Apresentamos a síntese dos resultados na forma de figuras.
\end{abstract}

Palavras-chave: investimento externo direto; BRICS; China; Brasil; África do Sul; Índia.

\section{CHINESE INVESTMENTS IN BRAZIL, SOUTH AFRICA AND INDIA: INSTITUTIONAL ARRANGEMENTS, ACTORS AND IMPACTS}

The BRICS (Brazil, Russia, India, China, and South Africa) were a landmark of the beginning of the 21st century and generated expectations of an alternative pole to the U.S-based world order. Although they have built different spaces for cooperation and common institutions in the last decade, the relationship among the BRICS countries is asymmetric, mainly due to China's economic weight. This article aims to provide an overview of China's investments in three other BRICS countries: Brazil, South Africa and India. Methodologically, we sought to show the main characteristics of Chinese investments by observing the following items: main companies and investment banks; investment volumes and main sectors; and participation of local government and private partner institutions. In addition, we have highlighted some programs and public policies that facilitate Chinese investment in each of these countries. Finally, we've tried to verify the existence or not of social, environmental and labor impacts that may be involved in these projects. In this sense, the article seeks to provide relevant aspects that allow us to identify similarities and differences in the economic relations of each of these countries with China. We present the synthesis of the results in the form of maps.

Keywords: foreign direct investments; BRICS, China; Brazil; South Africa; India.

1. Este artigo é resultado da pesquisa Investimentos da China no Brasil, África do Sul e Índia: Arranjos Institucionais, Atores e Impactos, com a coordenação da autora e com o apoio dos assistentes de pesquisa Yasmin Bitencourt, Monalisa Barcellos, Lucas Rezende e Thayane Nascimento (graduados em relações internacionais pela Universidade Federal Rural do Rio de Janeiro - UFRRJ). A pesquisa foi realizada pelo Instituto Políticas Alternativas para o Cone Sul (PACS) em parceria com a ActionAid Brasil. Sua publicação está disponivel em: <http://biblioteca.pacs.org.br/wpcontent/uploads/2019/02/1549884367Actionaind_PACs_18JAN.pdf>.

2.Professora adjunta de relações internacionais da UFFRJ.E-mail:<anagarcia@ufrrj.br>. 


\section{LAS INVERSIONES CHINAS EN BRASIL, SUDÁFRICA E INDIA: ARREGLOS INSTITUCIONALES, ACTORES E IMPACTOS}

El presente artículo oferece un panorama de las inversiones de China en los países BRICS: Brasil, Sudáfrica e India. El BRICS (Brasil, Rusia, India, China y Sudáfrica) constituyó un marco del inicio del siglo XXI generando la expectativa del surgimiento de um polo alternativo al orden mundial centrado en los EUA. A pesar de haber construído diferentes instancias de cooperación e instituciones comunes, en la última década, la relação entre los países BRICS es assimétrica, principalmente devido al peso econômico de China. En este artículo, buscamos destacar las características generales de las inversiones chinas en Brasil, Sudáfrica e India, observando los seguintes elementos: principales empresas y bancos de inversión; volúmen de las inversiones y principales sectores; gobierno local e instituciones privadas asociadas; marco político y jurídico que facilita la inversión china en cada uno de esos países y; finalmente, posibles impactos sociales, ambientales y laborales de esos projectos. Lejos de agotar el tema, dada la dinámica de las inversiones chinas y la complejidade de cada país, el artículo busca presentar aspectos y tendencias relevantes, que permiten identificar semejanzas y diferencias en las relaciones económicas de cada país com China. Presentamos la sintesis de los resultados en forma de mapas.

Palabras clave: investimento externo direto; BRICS; China; Brasil; Sudáfrica; India.

JEL: F21; F50.

Data de envio do artigo: 24/1/2020; Data de aceite: 31/3/2020.

\section{INTRODUÇÃO}

A formação do BRICS (Brasil, Rússia, Índia, China e África do Sul) representa um marco do início do século XXI. Esse grupo de países começou a se reunir ao longo da década de 2000, depois que o banco Goldman Sachs concebeu inicialmente o acrônimo com o intuito de identificar mercados promissores para grandes grupos econômicos e financeiros. Com a crise financeira global iniciada nos Estados Unidos em 2008, no entanto, a discussão sobre o papel do BRICS ganhou relevância, o que despertou a ideia de que a China, com outros países de economias denominadas emergentes, estaria desafiando a posição dominante de Estados Unidos, Europa e Japão. A crise consolidou o novo papel do grupo das vinte principais economias do mundo, o Grupo dos Vinte (G20), tendo sua cúpula de 2008 incluído os chefes de Estado do BRICS. Esses cinco países que chegaram a representar juntos quase $30 \%$ do produto interno bruto (PIB) mundial no ano da crise (2008) - representavam, em 2018, 20\% das entradas de investimento global e $24 \%$ do PIB mundial (UNCTAD, 2019, p. 5).

Após uma década, podemos observar que o BRICS passou por um adensamento institucional e temático, criando novas instituições e ampliando a esfera de cooperação intrabloco. Apesar dos esforços de cooperação, contudo, ainda persistem assimetrias econômicas e produtivas entre os cinco países do bloco, evidenciadas nas suas relaçóes comerciais. De acordo com dados divulgados pelo Ministério das Relaçóes Exteriores do Brasil sobre o comércio intra-BRICS, 
em 2016, Brasil, Rússia, Índia e África do Sul mostravam-se dependentes das exportaçóes para a China, com uma pauta altamente concentrada em insumos básicos, grãos, petróleo e minério brutos, enquanto as exportaçóes intrabloco da China foram compostas por produtos manufaturados e semimanufaturados. ${ }^{3}$ Assim, a tradicional divisão internacional do trabalho aparece reforçada no comércio entre os membros do bloco.

A assimetria da pauta comercial destaca o papel da China como potência econômica dentro do BRICS, o que também se reflete no investimento externo. A atuação do investimento externo no processo de desenvolvimento da China foi uma via de mão dupla: a partir da década de 1970, o país dá início à alavancagem de sua economia nacional com a criação de condiçôes para a acumulação de capital, nacional e estrangeiro, dentro de seu território, apoiado por um conjunto de regulaçóes e uma estratégia política e econômica a fim de que os investimentos estrangeiros entrassem e contribuíssem significativamente para estratégias nacionais de produção, comércio e inovação tecnológica. Por sua vez, a ascensão da China como uma potência econômica fez com que ela se tornasse também uma investidora internacional, com novos ciclos de acumulação de capital para fora. De acordo com a Conferência das Naçôes Unidas sobre Comércio e Desenvolvimento (United Nations Conference on Trade and Development - UNCTAD), a China permanece em segundo lugar no ranking mundial de investimentos, tanto como investidora externa (após o Japão) como receptora de investimento estrangeiro (após os Estados Unidos) (UNCTAD, 2019, p. 4 e 7). ${ }^{4}$ A expansão de suas empresas multinacionais e bancos para outros países e regiōes do Sul Global, na busca por recursos naturais e energéticos e novos mercados, leva a novos ciclos de expropriaçóes que podem impactar as populaçóes trabalhadoras.

Este artigo tem por objetivo fornecer um panorama geral sobre investimentos de empresas e bancos da China nestas outras três economias do BRICS: Brasil,

3. Comércio intrabloco: $89 \%$ das exportações brasileiras de insumos básicos, principalmente soja em grão, minério de ferro e óleo bruto de petróleo; $81 \%$ das exportações sul-africanas, essencialmente minério de ferro, carvão e manganês; $78,9 \%$ das exportações russas concentradas em óleo bruto de petróleo, óleo refinado de petróleo e carvão; e $45 \%$ das exportações indianas concentradas em óleo refinado de petróleo, hidrocarbonetos, minério de ferro e medicamentos em dose. Por sua vez, as exportações intrabloco da China são compostas por peças de aparelhos telefônicos, máquinas de processamento de dados e semicondutores. Ver World Integrated Trade Solution (WITS)/United Nations Comtrade Database, disponível em: <https://wits. worldbank.org/>. Acesso em: jun. 2020.

4. No fim dos anos 1990, o país havia lançado seu programa Going Out, fomentando grandes e médias estatais e grandes empresas privadas a se engajar no exterior. Posteriormente, a partir de 2004, houve um conjunto de medidas regulatórias destinadas a flexibilizar e facilitar projetos internacionais de empresas chinesas, por exemplo, a possibilidade de aquisições no exterior sem passar por aprovação prévia do governo para empresas que atuavam sem financiamento oficial. Essa regulação mais frouxa provocou um maior fluxo de capitais para fora da China e manobras para driblar os mecanismos de controle do governo, fazendo com que, em 2016, o Ministério de Comércio e Finanças e a administração central do governo chinês adotassem uma regulamentação mais rígida e restritiva (Jaguaribe, 2018, p. 25). Em 2016, o país chegou a realizar mais investimentos no exterior do que recebeu, respondendo por US\$ 183 bilhões dos investimentos estrangeiros diretos (IEDs) globais naquele ano, porém nos anos seguintes houve uma queda, chegando a US\$ 130 bilhões em 2018 (UNCTAD, 2019, p. 7). 
África do Sul e Índia. 5 Trazemos aqui um levantamento de dados sobre as características mais relevantes dos investimentos nestes países, observando os seguintes itens: estoque de volumes de investimentos; principais empresas chinesas em cada país por setor; e principais projetos que envolvem capital chinês. Além disso, destacamos os arranjos institucionais e atores envolvidos em cada projeto, tais como governos locais, instituições locais e chinesas, bancos públicos e privados, empresas nacionais ou de outros países não pertencentes ao bloco. Por fim, verificamos se há disputas em torno destes investimentos mediante informaçóes sobre impactos ambientais, sociais e trabalhistas envolvendo os investimentos chineses em cada país.

Em função da complexidade de cada país estudado e, em alguns casos, da dificuldade de acesso a informaçóes precisas e detalhadas, o artigo não pôde apresentar uma leitura aprofundada de cada caso, uma vez que a realidade dinâmica do tema provoca a alteração dos dados com relativa rapidez. Nesse sentido, sem almejar alcançar a plenitude de informaçóes, trouxemos uma amostra panorâmica, porém representativa dos investimentos chineses em três outros países do BRICS.

Iniciaremos pelos investimentos chineses no Brasil, depois na África do Sul e, por fim, na Índia. Concluímos que a China pauta sua atuação externa de acordo com sua estratégia nacional de desenvolvimento (energético, produtivo, tecnológico e financeiro) e, portanto, adapta suas necessidades a cada país com o qual se relaciona. Se a presença chinesa na África do Sul é mais diversificada e antiga, envolvendo, em ampla medida, políticas de ajuda e cooperação internacional, além dos ganhos comerciais, no Brasil, a entrada da China se acelerou nos últimos anos e vem sendo concentrada nos setores de commodities e energia. É notória a dependência comercial do Brasil e da África do Sul ante a China, o que, por sua vez, não se verifica em relação à Índia. Entre as duas potências asiáticas, a relação é permeada por tensôes geopolíticas, apesar da crescente aproximaçáo comercial e empresarial.

\section{INVESTIMENTOS CHINESES NO BRASIL}

A presença chinesa no Brasil tem se intensificado por meio de diversas frentes, entre as quais se destacam comércio, IEDs e empréstimos. $\mathrm{O}$ comércio entre ambos os países passou de US\$ 3,2 bilhōes para US\$ 66,3 bilhóes, entre 2001 e 2015, e vem acumulando superavit desde 2009 (Costa e Mendonça, 2017, p. 74). Apesar do superavit, a pauta exportadora do Brasil para a China é composta majoritariamente por soja em grãos e minério de ferro, enquanto da China para o Brasil compóe-se de bens manufaturados. ${ }^{6}$ Esse desequilíbrio também

5. A Rússia não foi incluída na pesquisa que deu origem a este artigo, uma vez que é um país cuja relação com a China se dá sob bases geopolíticas, e menos comerciais, o que exigiria uma discussão mais aprofundada.

6. Disponível em: <http://comexstat.mdic.gov.br/pt/comex-vis>. 
está refletido na pauta comercial entre a China e a América Latina. Segundo a Comissão Econômica para a América Latina e o Caribe (CEPAL), em 2016, 72\% das exportaçôes oriundas da América Latina para a China foram de produtos primários, enquanto, para o resto do mundo, as exportaçóes desses produtos representaram apenas $27 \%$, equilibrando com manufaturas de tecnologia baixa, média e alta (CEPAL, 2018, p. 41).

Além das relaçôes comerciais, Brasil e China alavancaram sua relação também por meio de investimentos de empresas públicas e privadas. De acordo com o relatório do Conselho Empresarial Brasil-China (CEBC) mais recente sobre investimentos chineses no Brasil, entre 2007 e 2018 foram investidos US\$ 58 bilhōes em 145 projetos efetivamente realizados (CEBC, 2019, p. 8). ${ }^{7}$ O Brasil concentrou 49\% dos investimentos chineses destinados à América Latina e ao Caribe entre 2007 e 2018, sendo que o estado de São Paulo acumula 35\% deste total (op. cit., p. 17 e 22).

A entrada de capitais chineses no Brasil foi constituída, segundo esse conselho, por quatro diferentes momentos. O primeiro, em 2010, foi marcado pelo investimento em atividades ligadas às commodities, principais produtos exportados para a China. No segundo momento, entre 2011 e 2013, os investimentos se direcionaram para o setor industrial, tendo em vista o interesse de empresas chinesas no consumo doméstico brasileiro, especialmente o setor automotivo e o de eletroeletrônicos. A partir de 2013, observou-se um terceiro momento, em que as empresas chinesas passaram a investir no setor de serviços, em especial no de serviços financeiros, com o estabelecimento de bancos chineses no país. Na fase mais recente, a partir de 2014, os investimentos chineses entram de forma massiva na área energética, tanto na produção quanto na transmissão de energia elétrica, no agronegócio e na infraestrutura (CEBC, 2017, p. 7-10).

Apesar dessa diversificação nos últimos anos, o setor que mais se destaca é o energético. Entre 2007 e 2018, 53\% dos investimentos chineses na América Latina foram para este setor, em grande parte por causa do Brasil, que atraiu dez dos doze principais investimentos do setor na região (CEBC, 2019, p. 24). Isso se explica pela grande procura por recursos naturais para suprir a demanda industrial chinesa. De acordo com Colombini Neto (2016, p. 62), 66\% dos investimentos em energia foram realizados na área petroquímica, totalizando um montante de US\$18,250 bilhóes. As principais multinacionais chinesas nesse setor são: a Sinopec, a maior refinaria de petróleo chinesa, que no Brasil tornou-se uma das principais investidoras na extração de petróleo e gás na camada

7. Este número é um pouco inferior ao volume informado pelo banco de dados China Global Investment Tracker. De acordo com o CEBC, os investimentos somam US\$ 102 bilhões se contarmos os que foram anunciados e concretizados, o que resulta em um percentual de concretização de $56 \%$ dos aportes anunciados (CEBC, 2019, p. 8). 
pré-sal; a China National Petroleum Corporation (CNPC) e a China National Offshore Oil Corporation (CNOOC), que tiveram participação de 10\%, cada uma, no consórcio do campo de Libra em 2013; a State Grid, que investe na área de transmissão de energia e está presente em diversos projetos, tendo até 2015 um total de $6.040 \mathrm{~km}$ de linhas de transmissão pelo Brasil; ${ }^{8}$ e a China Three Gorges Corporation (CTG), que se destaca com megaprojetos no setor de energia hidroelétrica. De acordo com o relatório mais recente do CEBC, State Grid e CTG somaram, em 2018, US\$ 1,2 bilhão em doze projetos no Brasil (CEBC, 2019, p. 13).

A participação de grupos econômicos da China se intensifica também no agronegócio, destacando-se a aquisição de $57,6 \%$ da comercializadora brasileira de grãos Brasil Fiagril pela chinesa Hunan Dakang International Food and Agriculture (CEPAL, 2017, p. 61). Outro setor de destaque na nova fase dos investimentos chineses no Brasil é a área de transporte e infraestrutura. No setor da aviação civil, a Hainan Airlines adquiriu 23,7\% de participação da empresa Azul Linhas Aéreas (op. cit., p. 60). Na construção civil, por sua vez, a China Communications Construction Company (CCCC) adquiriu 80\% do capital da Concremat Engenharia, além de participar também de projetos no setor portuário (CEBC, 2017, p. 24).

FIGURA 1

Investimentos chineses no Brasil

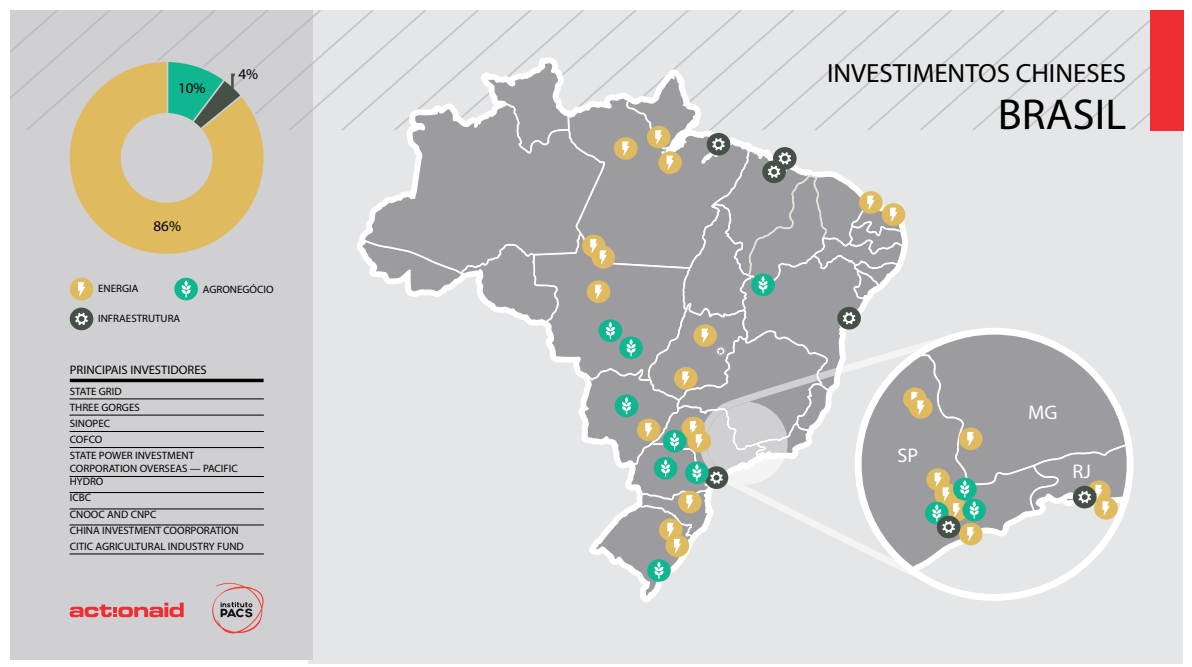

Fonte: Garcia (2018, p. 32-33).

Obs.: Figura cujos leiaute e textos não puderam ser padronizados e revisados em virtude das condições técnicas dos originais (nota do Editorial).

8. Informação disponibilizada na página web da empresa. 
A aproximação entre a China e o Brasil também pode ser observada por meio dos créditos fornecidos por aquele país, que se concentram no setor de energia e de infraestrutura. Segundo dados da CEPAL (2018, p. 23), os empréstimos chineses para os países da América Latina entre 2005 e 2016 chegaram a um volume de US 141 bilhóes, sendo 80\% destes realizados pelo Banco de Desenvolvimento da China (China Development Bank - CDB). Nesse período, os países que mais se beneficiaram dos financiamentos foram Venezuela, Brasil, Equador e Argentina. O Brasil, em especial, recebeu o correspondente a $26 \%$ do financiamento total chinês na regiāo (CEPAL, 2018). Podemos ressaltar a modalidade loan-for-oil, na qual os pagamentos de créditos sáo feitos por meio de barris de petróleo, atividade que somou, em quatro anos, US\$ 74 bilhóes em empréstimos para a América Latina e o Caribe (op. cit., p. 24). Segundo a CEPAL, este crescimento significativo dos fluxos de financiamento para a América Latina é parte da estratégia chinesa para a diversificação de divisas dos países desta regiáo, com vistas a promover o uso internacional da sua moeda, o renminbi (CEPAL, 2018).

Outro instrumento de financiamento chinês, realizado de modo indireto, é por meio do Novo Banco de Desenvolvimento (New Development Bank - NDB) do BRICS, que abriu o Escritório Regional das Américas com sede em São Paulo, o qual deve ampliar as operaçóes do banco no Brasil (NDB, 2018b). Entre 2016 e 2019, o NDB financiou sete projetos no Brasil, em setores distintos. O primeiro foi o empréstimo concedido ao Banco Nacional de Desenvolvimento Econômico e Social (BNDES) com o objetivo de financiar outros subprojetos em energias renováveis. Nas áreas de infraestrutura e transporte, os empréstimos foram para os governos dos estados do Pará e do Maranháo. Na área de infraestrutura sustentável, o NDB aprovou um financiamento sem garantia soberana para a Petrobras. Por fim, por ocasião da cúpula do BRICS em Brasília e da abertura do escritório regional do banco no país, o NDB acelerou de forma significativa sua atuação no Brasil em 2019 com três novos empréstimos: para o Fundo Clima, do Ministério do Meio Ambiente, que recebeu crédito de US $\$ 500$ milhóes em subprojetos na área ambiental $;{ }^{10}$ para a mineradora Vale, que recebeu um montante de US $\$ 300$ milhóes; ${ }^{11} \mathrm{e}$ para o fundo governamental Pátria para infraestrutura, que recebeu US\$100 milhōes. Observamos que, em meio às incertezas quanto à condução do novo governo de Jair Bolsonaro e das suas relaçóes com o BRICS, a concessão de novos empréstimos

9. Todos os projetos aqui mencionados encontram-se disponíveis em: <https://www.ndb.int/projects/list-of-allprojects/approved-projects/>.

10. 0 empréstimo ocorreu em meio às queimadas na Amazônia, em um ambiente internacional de duras críticas à política ambiental do governo brasileiro recém-eleito. Disponível em: <https://www.ndb.int/fundo-clima-brazilnational-climate-fund-project/>.

11. Diante das tragédias de Mariana e Brumadinho, podemos questionar em que medida o banco, ao conceder empréstimo à Vale, poderá conciliar seus objetivos de financiar projetos de infraestrutura e, simultaneamente, garantir a sustentabilidade, o meio ambiente e os direitos da população nos territórios onde os projetos serão executados. Disponivel em: <https://www.ndb.int/north-region-transportation-infrastructure-improvement-project/>. 
efetuados pelo banco ajudou a legitimar sua atuação no país na preparação para a cúpula que ocorreu em novembro daquele ano.

A aproximação econômica entre China e Brasil tem mobilizado diversas instâncias e atores, que incluem entidades governamentais, alianças com corporaçóes e negócios com pequenas empresas. Líderes políticos têm fomentado o estreitamento das relaçóes sino-brasileiras mediante parcerias estratégicas, protocolos de investimentos e memorandos de entendimento durante visitas presidenciais. Nesse sentido, a diplomacia apresenta-se como promotora destas relaçóes. ${ }^{12}$ As visitas ao Brasil do presidente chinês Xi Jinping em julho de $2014 \mathrm{e}$ do primeiro-ministro Li Keqiang em maio de 2015 foram catalisadoras de acordos de investimentos. $\mathrm{Na}$ visita do primeiro-ministro, foram assinados 35 acordos entre empresas e instituiçóes de ambos os países e em diversos setores, que somam um montante de US\$ 53 bilhóes, nas áreas de planejamento, infraestrutura, comércio, energia e mineração (Colombini Neto, 2016).

O impeachment de Dilma Rousseff em 2016, que acelerou o "giro à direita" na América do Sul, não resultou em mudanças para as empresas chinesas. Elas mantiveram seus interesses e expectativas de ganhos na nova onda de liberalizaçáo da região. Notoriamente, a primeira viagem presidencial de Michel Temer, ainda como presidente interino, foi para a China em 2016, a fim de participar da cúpula do G20, em Hangzhou. Temer se reuniu com empresários chineses em Xangai para apresentar sua agenda de reformas, com o objetivo de atrair investimentos para o Brasil. ${ }^{13}$ Em 2017, Temer fez uma segunda viagem à China para participar da cúpula do BRICS, e levou uma comitiva de governo e empresários com o intuito de vender pacotes de concessóes - que incluíam a privatização da Casa da Moeda, da Eletrobras e de aeroportos nacionais, como o de Congonhas - e de discutir um acordo de cooperação entre a Eletronuclear e a China Nuclear para Angra $3 .{ }^{14}$ Em 2018, ao participar da cúpula do BRICS na África do Sul, Michel Temer se reuniu bilateralmente com o presidente chinês Xi Jinping para tratar dos investimentos chineses dentro do programa de concessóes e privatizaçôes, além das questôes que envolvem as barreiras comerciais, que impactam na comercialização do açúcar e do frango, de interesse do agronegócio brasileiro. ${ }^{15}$

Em 2018, a eleição no Brasil gerou incertezas em relação à China. De um lado, o presidente eleito Jair Bolsonaro reafirmou um alinhamento aos Estados Unidos e

12. Um marco histórico das relações diplomáticas entre Brasil e China foi o reconhecimento, em meados dos anos 1970, do princípio de "uma só China" pelo governo brasileiro, que desde então não mantém relações diplomáticas com Taiwan.

13. Disponível em: <https://brasil.elpais.com/brasil/2016/09/01/politica/1472682956_242080.html>.

14. Disponível em: <https://www.valor.com.br/politica/5095236/temer-leva-comitiva-esvaziada-para-china>.

15. Disponível em: <https://www.valor.com.br/brasil/5688963/temer-competitividade-depende-de-maior-aberturainvestimentos>. 
ao governo de Donald Trump, e expressou críticas à entrada de investidores chineses no Brasil. ${ }^{16}$ De outro, setores exportadores com grande peso na economia brasileira, em especial os de commodities agrícolas e minerais, sendo altamente dependentes das vendas para o mercado chinês. ${ }^{17}$ Nesse sentido, posicionar-se ao lado dos Estados Unidos em meio à "guerra comercial" com a China pode gerar contradiçôes com setores internos poderosos. Por sua vez, os programas de privatizaçóes de empresas e serviços públicos, anunciados pelo governo, deverão contar com a participação de grandes investidores chineses, aumentando ainda mais sua inserção no Brasil (Craveiro, 2018). É possível afirmar que a posição do governo se revela ambígua, uma vez que, ideologicamente, alinha-se aos Estados Unidos, mas pragmaticamente não pode dispensar o mercado chinês para as exportaçóes brasileiras, e dificilmente poderá impedir, em uma lógica de livre mercado, que investidores chineses com a melhor oferta façam aquisiçóes em privatizações.

Além da diplomacia como instrumento de fortalecimento entre as relaçóes sino-brasileiras, identifica-se a criação de várias entidades e fóruns para este fim. Entre estas instâncias, destaca-se, em primeiro lugar, o Fundo Brasil-China de Cooperaçáo para Expansão da Capacidade Produtiva, ${ }^{18}$ arquitetado durante o governo Dilma Rousseff a partir de 2015 e ativado pelo governo Michel Temer em 2017. O fundo tem como objetivo, segundo o BNDES, ${ }^{19}$ disponibilizar financiamentos para projetos em setores ligados a infraestrutura, logística, energia, indústria, recursos minerais, agroindústria, novas tecnologias e serviços digitais, que sejam executados exclusivamente no Brasil. Para esse fundo foram disponibilizados, segundo Amorim (2018, p. 4), US\$ 20 bilhóes, sendo US\$ 15 bilhóes provenientes do China-LAC Industrial Cooperation Investment Fund (Claifund) e US\$ 5 bilhóes de instituiçóes brasileiras, como a Caixa Econômica Federal e o BNDES.

Um outro espaço político que também apoia a expansão do capital chinês no Brasil e na América Latina é o Fórum China-CELAC (Comunidade de Estados Latino-Americanos e Caribenhos). Lançado em Havana em 2014, este fórum tem como finalidade se tornar uma instância de diálogo político e de outros temas, e estreitar os vínculos de cooperação entre a China e os países da América Latina e o Caribe. O primeiro fórum de ministros China-CELAC foi realizado em Pequim em 2015. No âmbito do Fórum China-CELAC, o presidente chinês

16. Disponível em: <https://noticias.uol.com.br/politica/eleicoes/2018/noticias/reuters/2018/10/25/discurso-antichina-de-bolsonaro-causa-apreensao-sobre-negocios-com-o-pais.htm>.

17. Disponível em: <https://valor.globo.com/empresas/noticia/2018/10/17/brasil-e-china-tem-dependencia-mutuadiz-presidente-da-vale.ghtml>.

18. Informações sobre o fundo estão disponíveis em: <https://agenciabrasil.ebc.com.br/economia/noticia/2017-05/ governos-do-brasil-e-da-china-lancam-fundo-para-obras-de-infraestrutura> e <http://cebc.org.br/sites/default/files/ digitalizar0008.pdf $>$.

19. Disponivel em: <https://www.bndes.gov.br/wps/portal/site/home/imprensa/noticias/conteudo/bndes-seraoperador-preferencial-do-fundo-brasil-china> . 
Xi Jinping anunciou, em 2015, investimentos nos próximos dez anos nos países da região no volume total de US\$ 250 bilhóes. ${ }^{20}$ Segundo Vadell $(2018$, p. 16), a CEPAL vem se tornando um órgão assessor da CELAC, ao dar apoio técnico e acompanhar suas atividades. Atualmente, segundo documento oficial, o Fórum China-CELAC se incorporou à Cúpula China-LAC, que é organizada pelo Conselho Chinês para a Promoção do Comércio Internacional (China Council for the Promotion of International Trade - CCPIT) e pelo Banco Interamericano de Desenvolvimento (BID) (China-CELAC Forum, 2016).

Diante do crescimento do comércio e dos investimentos entre Brasil e China, foi criada a Comissão Sino-Brasileira de Alto Nivel de Concertação e Cooperação (COSBAN) ainda em 2004, com a finalidade de coordenar e orientar a cooperação bilateral entre os países nos mais diversos âmbitos. ${ }^{21}$ De acordo com Pecequilo e Junqueira (2016), na COSBAN foram elaborados três planos: i) o Plano de Açáo Conjunta 2010-2014, que visou fortalecer a relação entre os dois países na cooperação comercial e econômica; ii) o Plano Decenal de Cooperação, entre 2012 e 2021, que estabeleceu o foco das relaçóes Brasil-China nas áreas de ciência e tecnologia, energia e infraestrutura, comércio e cooperação cultural, com a intenção de diversificar as áreas de investimento; e iii) o Plano de Ação Conjunta 2015-2021, que complementa o Plano Decenal assinado em 2012, com o propósito de fortalecer os acordos bilaterais entre os países (Pecequilo e Junqueira, 2016).

O primeiro Plano de Ação Conjunta é marcado pela assinatura de vários acordos no setor energético. Entre eles está o acordo de crédito com o CDB, de 2009, assegurado pelo mecanismo loan-for-oil, bem como o empréstimo de 2015 do CDB para a Petrobras, que teria ajudado a amenizar a crise institucional que a empresa atravessava (Shoujun e Miranda, 2016, p. 13). Por sua vez, o segundo Plano de Ação Conjunta destaca o papel da COSBAN como principal órgão político responsável pelos documentos e pelas relaçóes bilaterais sino-brasileiras. Tanto o segundo Plano de Ação quanto o Plano Decenal se aproximam no que tange à coordenação em pesquisa e desenvolvimento $(\mathrm{P} \& \mathrm{D})$ e no incentivo às iniciativas bilaterais, além do fomento à área energética, mineral e agrícola.

Alguns estudos trazem uma perspectiva mais crítica à expansão dos investimentos chineses, especialmente nas atividades ligadas aos recursos naturais. $\mathrm{Na}$ agricultura, apesar das restriçôes legais à compra de terras por estrangeiros, acabou ocorrendo um aumento do investimento chinês em terras e na produção do agronegócio brasileiro, por meio da aquisição de ativos financeiros de empresas do agronegócio, com o objetivo de controlar diferentes etapas da cadeia

20. Disponível em: <https://valor.globo.com/brasil/coluna/fundo-brasil-china-escolhe-projetos-para-aportes-de-us-24bi.ghtml>.

21. Disponivel em: <http://www.itamaraty.gov.br/pt-BR/notas-a-imprensa/2564-comunicado-conjunto-entre-a-republicafederativa-do-brasil-e-a-republica-popular-da-china-pequim-em-12-de-abril-de-2011>. 
de valor de commodities (Escher, Wilkinson e Pereira, 2018). Assim, investidores estrangeiros, entre eles os chineses, puderam "escapar"da legislação restritiva da compra direta de terras ao aumentar sua inserção financeira no agronegócio.

Impactos dos investimentos chineses sobre comunidades locais evidenciam o próprio modelo de desenvolvimento adotado no Brasil, voltado para a indústria extrativa e infraestruturas, envolvendo conflitos socioambientais. Segundo Shoujun e Miranda (2016, p. 24), organizaçôes da sociedade civil brasileira, grupos indígenas e sindicatos são os principais críticos à instalação de megaprojetos, como o da barragem de Belo Monte, que recebeu investimentos da estatal chinesa State Grid em suas linhas de transmissão. Críticas e resistências diante da construção da usina chegaram à Organização dos Estados Americanos (OEA), que cobrou explicaçóes do governo brasileiro sobre o projeto. Outro exemplo trazido por Shoujun e Miranda (2016, p. 24-25) são as greves que paralisaram a extração de petróleo no campo de Libra, em que as empresas chinesas CNOOC e CNPC adquiriram 10\% de participação cada, por meio do investimento de US\$ 1,28 bilhão.

Outro exemplo é o caso do Complexo Tapajós, que corresponde a um conjunto de seis megaprojetos hidroelétricos, nos quais os capitais chineses têm participação relevante. De acordo com Aguiar (2017, p. 69), a consolidação deste projeto representa a prova de fogo para as empresas chinesas, tendo em vista a grande resistência dos povos locais. As diferentes tensôes entre a representação de interesses de grupos locais, nacionais e estrangeiros revelariam as contradiçóes do processo capitalista extrativo, levando em conta as assimetrias de poder existentes entre a população local e os projetos que se instalam em seus territórios. Para Aguiar (2017), os interesses das multinacionais chinesas se entrelaçam aos dos grandes grupos econômicos no Brasil, em contraposição aos direitos dos que vivem nos territórios.

De qualquer modo, é notória a relação de dependência entre o Brasil e a China, aumentada ante a força de empresas multinacionais chinesas na última década. O Brasil continua ocupando um papel secundário nas cadeias globais de valor como produtor e exportador de matérias-primas e produtos primários. Com isso, comunidades, indígenas e trabalhadores se veem diante de novos enfrentamentos na luta global por direitos e por um outro desenvolvimento, que atenda efetivamente às necessidades das camadas trabalhadoras.

\section{INVESTIMENTOS CHINESES NA ÁFRICA DO SUL}

A China lidera a presença do BRICS na África, uma vez que é um dos principais parceiros comerciais e investidores no continente, sendo também a maior origem das importaçóes africanas (Cheru e Obi, 2010). De acordo com Shen (2013), até o início dos anos 2000, quase todo o capital direcionado da China para a África 
representava "ajuda internacional", porém, a partir de 2005, a expansão do capital chinês para a África deu um salto quantitativo e qualitativo. Empresas estatais chinesas de médio e grande porte se espalharam e passaram a desempenhar um papel relevante em todo o continente africano (Shen, 2013, p. 3). He e Zhu (2018) revelam que, entre 2003 e 2014, o estoque de investimentos chineses na África saltou de US\$ 491 milhóes para US\$ 32,4 bilhóes. É precisamente em 2008, com a crise econômica internacional, que ocorre a principal aquisição chinesa na África: a compra em participação de $20 \%$ no Standard Bank da África do Sul, por US\$ 5,6 bilhóes, pelo Banco Industrial e Comercial da China (He e Zhu, 2018, p. 110). Com sede em Joanesburgo, o Standard Bank opera em dezoito países africanos, e sua aquisição facilitaria o acesso a recursos naturais e um crescente aumento do comércio. ${ }^{22}$ Desse modo, passadas duas décadas, a África do Sul é hoje a principal receptora de IED chinês na África Subsaariana.

O presidente Xi Jinping, em artigo de jornal por ocasiâo da visita à África do Sul para a cúpula do BRICS em Joanesburgo, em 2018, afirmou que o país também se tornou o principal parceiro comercial da China no continente africano. O comércio mútuo alcançou em 2017 o volume de US\$ 39,7 bilhôes, aumentando em vinte vezes desde o início das relaçóes diplomáticas em 1998. O investimento chinês na África do Sul cresceu oitenta vezes, significando um estoque acumulado de mais de US\$ 20 bilhôes (Jinping, 2018). Esses laços já haviam se fortalecido durante o governo Jacob Zuma, por meio da elevaçáo da África do Sul a um parceiro estratégico da China e da inclusão do país em uma "parceria estratégica abrangente", em 2011, para aprofundar a cooperação econômica. Dessa parceria estratégica resulta uma comissão binacional e reunióes sucessivas de "diálogo estratégico" entre os dois países. ${ }^{23}$

O investimento chinês na África do Sul é menos concentrado e mais diversificado que no Brasil, e destacam-se, além do financeiro, os setores de metais, infraestrutura e imobiliário. Alguns investimentos em metais incluem empréstimos do $\mathrm{CDB}$ ao Jinchuan Group, que é a maior produtora de cobre da China e tem $60 \%$ a $70 \%$ de seus ativos situados no continente africano. ${ }^{24}$ Por sua vez, a Sinosteel estabeleceu uma joint venture na África do Sul com a Samancor Corporation, uma das principais empresas de minério de cromo no país. ${ }^{25}$

No setor imobiliário, destacam-se os investimentos da Tangshan Jidong Cement e da Shanghai Zendai, ambos com financiamento do CDB em 2010. O China Minsheng Investment Group investiu na construção de moradias a

22. Disponivel em: <https://www.nytimes.com/2007/10/26/business/worldbusiness/26iht-26icbc.8062473.html>.

23. Disponível em: <http://www.fmprc.gov.cn/mfa_eng/wjb_663304/zzjg_663340/fzs_663828/ gjlb_663832/3094_664214/>.

24. Disponível em: <http://www.polity.org.za/article/strategising-chinasouth-africa-relations-2013-03-26>.

25. Disponivel em: <http://www.chinadaily.com.cn/business/2006-12/22/content_765597.htm>. 
preços acessíveis na África do Sul como parte do programa Belt and Road Initiative (BRI). ${ }^{26}$ Por sua vez, no setor de transportes, a empresa Beijing Automotive Group (BAIC) e a First Automobile Works investiram na construção de uma fábrica de montagem de veículos na zona econômica especial (ZEE) em Coega, no Cabo Oriental. ${ }^{27}$

Outro setor importante é o de telecomunicaçóes, com investimento da estatal Zhong Xing Telecommunication Equipment (ZTE), segunda na China e quinta maior do mundo no setor. ${ }^{28} \mathrm{~A}$ estatal é um dos membros principais da Associação Sul-Africana de Comércio e Economia da China (South Africa-China Economy and Trade Association - SACETA), desfrutando, assim, de facilitação e promoção de capitais. ${ }^{29}$ Seu investimento na África do Sul, em 2010, incluiu US\$ 380 milhóes na Cell C. Também no setor de telecomunicaçôes, a Huawei investiu US\$ 211 milhóes na Telkom S/A, em 2008. A Huawei afirmou que pretende auxiliar o governo da África do Sul a alcançar 100\% de penetração de banda larga até $2020 .{ }^{30}$

FIGURA 2

Investimentos chineses na África do Sul

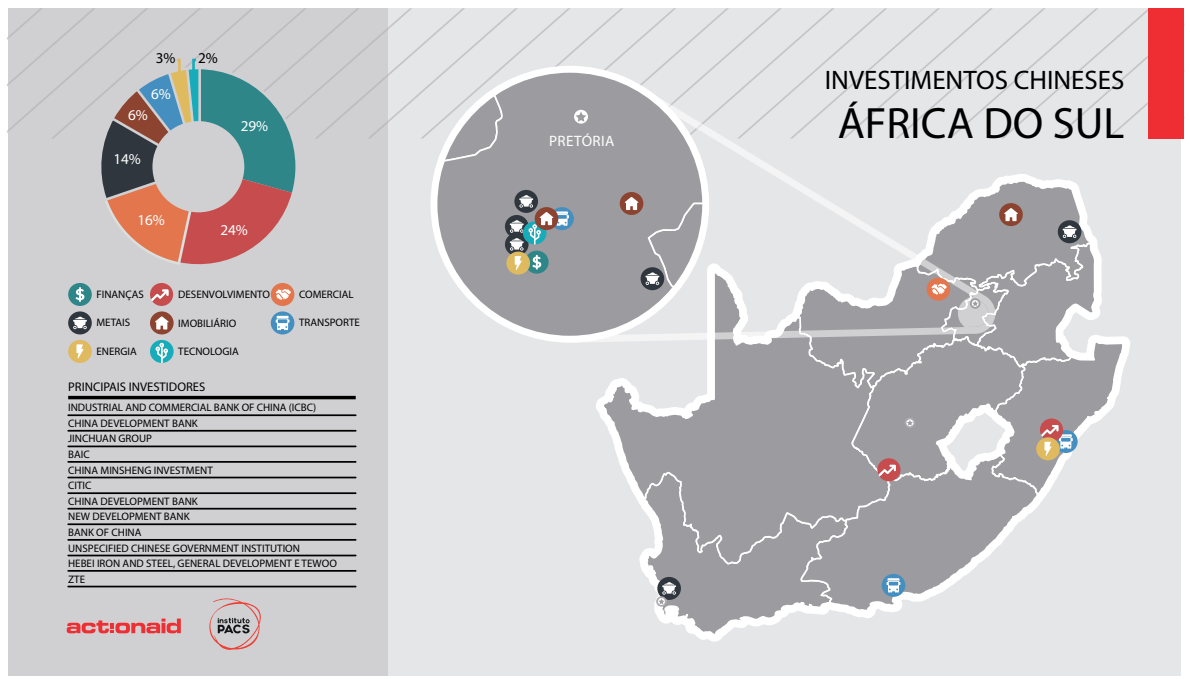

Fonte: Garcia (2018, p. 52-53).

Obs.: Figura cujos leiaute e textos não puderam ser padronizados e revisados em virtude das condições técnicas dos originais (nota do Editorial).

26. Disponivel em: <https://www.scmp.com/business/companies/article/2115439/minsheng-investments-buildingarm-seals-us129bn-south-african>.

27. Disponível em: <http://www.polity.org.za/article/strategising-chinasouth-africa-relations-2013-03-26>.

28. Disponível em: <http://www.newsecuritylearning.com/index.php/archive/75-chinas-mighty-telecom-footprint-in-africa> . 29. Disponivel em: <https://www.itweb.co.za/content/okYbe97X3YBvAWpG>.

30. Disponivel em: <http://wwww0.sun.ac.za/ccs/wp-content/uploads/2015/03/CCS_PB_SA-CHINA_Engagement_2015.pdf>. 
O CDB é o principal órgão de financiamento aos investimentos externos na África por meio do Fundo de Desenvolvimento China-África (China-Africa Development Fund - CAD Fund). ${ }^{31}$ Fundado em 2007, o fundo objetiva "encorajar e apoiar empresas chinesas para investir na África". ${ }^{32} \mathrm{Em} 2015$, o CAD Fund anunciou recursos em US\$ 5 bilhóes, podendo chegar ao capital total de US\$ 10 bilhóes para investimentos nos setores de agricultura, infraestrutura, manufatura, parques industriais e recursos naturais..$^{33}$ Entre os financiamentos específicos na África do Sul estão a fábrica de produção de cimentos da empresa Jidong Cement Group, o parque industrial de eletrodomésticos da Hinsense Group e a planta de montagem de automóveis China FAW. ${ }^{34}$

Outra forma indireta de financiamento chinês para a África do Sul se dá por meio do NDB do BRICS. Entre 2016 e 2019, seis projetos ${ }^{35}$ receberam financiamentos do banco. Destes seis, dois foram para a empresa de energia Eskom, para projetos em energia renovável e redução de emissóes em uma usina de carvão. Antes deles, o primeiro havia sido concedido ao Banco de Desenvolvimento da África do Sul para projetos em energia limpa. Mais recentemente, outros dois empréstimos foram concedidos: um para a empresa Industrial Development Corporation (IDC), para um projeto em energia; e outro para a Agência Nacional de Estradas (South African National Roads Agency Limited - SANRAL), para projetos em transporte.

O empréstimo do NDB à empresa Transnet para a ampliação do Porto de Durban (US\$ 200 milhôes) foi objeto de críticas por parte de D’Sa e Bond (2018). Segundo os autores, o projeto atende a um complexo portuário com atividades petroquímicas altamente poluentes, revelando que a expansão do porto não foi acompanhada de consultas ou análises adequadas (D'Sa e Bond, 2018, p. 180). Assim, formou-se um movimento de resistência, a Aliança Ambiental Comunitária do Sul de Durban (South Durban Community Environmental Alliance - SDCEA), que vem denunciando os impactos ambientais e sociais sobre a saúde da comunidade vizinha ao porto. D'Sa e Bond (2018) lembram que a empresa já havia recebido US\$ 5 bilhóes do CDB em 2013 (quando ocorreu a cúpula do BRICS em Durban) para contratar uma empresa chinesa de construção civil (a Shanghai Zhenhua Heavy Industries) com a finalidade de construir um novo contêiner. $\mathrm{O}$ empréstimo também beneficiou outra empresa chinesa, a South China Rail, para exportar locomotivas (op. cit., p. 182).

Um marco das relaçóes sino-africanas foi a criação do Fórum de Cooperação China-África (Forum on China-Africa Cooperation - FOCAC), iniciado em

31. Disponivel em: $<$ http://en.cadfund.com>.

32. Disponível em: <http://en.cadfund.com/Column/25/0.htm>.

33. Disponível em: <http://en.cadfund.com/Column/25/0.htm>.

34. Brochura disponivel em: <http://www.cadfund.com/WebSite/cadf/Upload/File/201312/20131231154138105396.pdf>. 35. Todos os projetos estão disponiveis em: <https://www.ndb.int/projects/list-of-all-projects/approved-projects/>. 
Pequim em 2000. Com a institucionalização do fórum, alguns autores consideram que há uma nova forma de coalizão e cooperação: fomentam-se o investimento empresarial, a troca de experiência, a criação de joint ventures e, sobretudo, a participaçâo de empresas chinesas em projetos de desenvolvimento econômico e de infraestrutura no continente africano (Lopes, Nascimento e Vadell, 2013, p. 88). Nesse sentido, o FOCAC institucionaliza a relação entre investimentos e ajuda internacional, colocando-os em um mesmo "pacote". Por trás disso há a ideia de que a China atenderia aos interesses de desenvolvimento dos países africanos. ${ }^{36}$

A cúpula do FOCAC em 2015 ocorreu precisamente na capital da África do Sul, Joanesburgo, onde foi lançado o Plano de Açấo 2016-2018. ${ }^{37}$ No que tange aos investimentos, o plano apoia e encoraja a atuaçáo de empresas chinesas na África quando trata de vários setores, como agricultura, energia, infraestrutura, indústria, entre outros. Enfatiza os investimentos em ZEEs e parques industriais, eixo central para os investimentos chineses na África do Sul. Vale notar que empresários das principais multinacionais chinesas e africanas participam do China-Africa Business Forum, ${ }^{38}$ reunindo-se com ministros de comércio, finanças, investimentos etc., com o objetivo de discutir prioridades e acelerar investimentos em setores considerados estratégicos.

Entre os mecanismos políticos de apoio e promoção do investimento estrangeiro na África do Sul está um conjunto de legislaçôes que oferece proteção aos investidores. Em um relatório, o capítulo sul-africano do BRICS Business Council (2016, p. 4) identifica como políticas para atração de investimento estrangeiro a ampla liberalização tarifária - vigente desde 1994-, o Plano Nacional de Desenvolvimento ${ }^{39}$ e o Plano de Ação da Política Industrial, que incentivam a incorporação de empresas, a produção e, também, a absorção de mão de obra. ${ }^{40}$ Outro mecanismo é a nova Lei de Proteção ao Investimento, de 2015, que prevê a criação de condições favoráveis ao investimento, o estímulo à iniciativa empresarial e a intensificação da cooperação econômica entre os Estados, com base na igualdade e em benefícios mútuos entre investidores domésticos e estrangeiros. ${ }^{41} \mathrm{O}$ governo sul-africano coloca-se como responsável pela criação e manutenção de um arcabouço legislativo sólido para a promoção e a proteção de todos os investimentos, nacionais ou estrangeiros. $\mathrm{Na}$ visão dos investidores, a lei seria estratégica, visto que o IED se direciona a ambientes com sólidos direitos de propriedade e estado de direito (Chen, Dollar e Tang, 2015, p. 7). Por fim, China e África do Sul mantêm um Tratado Bilateral de Investimento (TBI) desde 1998, que

36. Disponível em: <http://english.gov.cn/archive/white_paper/2014/08/23/content_281474982986592.htm>.

37. Disponível em: <http://www.fmprc.gov.cn/mfa_eng/zxxx_662805/t1323159.shtml>.

38. Disponivel em: <http://www.xinhuanet.com/english/2018-08/31/c_137434284.htm>.

39. Disponível em: <https://www.gov.za/issues/national-development-plan-2030>.

40. Disponivel em: <https://www.gov.za/documents/industrial-policy-action-plan-ipap-201819-202021-9-may-2018-0000> .

41. Disponível em: <https://investmentpolicy.unctad.org/investment-laws/laws/157/investment-act>. 
prevê proteger investimentos chineses no país, proporcionando amplas garantias aos investidores em termos de tratamento nacional, livre transferência de divisas, ampla definiçẫo de investimento, além de proteção contra nacionalização, expropriação e medidas equivalentes. ${ }^{42}$ Vale ressaltar que a África do Sul vem, nos últimos anos, cancelando esse tipo de tratado ou alterando seus termos; no entanto, o tratado com a China permanece em vigência. ${ }^{43}$

Entre os investimentos chineses na África do Sul, podemos destacar os projetos de ZEEs, que são áreas destinadas à atividade industrial, contando com a concessão de benefícios aos investidores. Thompson, Wet e Awaseh (2018) revelam que as ZEEs representam o pacote que vincula a ajuda bilateral chinesa ao investimento direto focado nessas zonas industriais. Segundo os autores, as ZEEs foram apresentadas como "cura" para os problemas das economias africanas, visto que seriam impulsoras do desenvolvimento industrial, da diversificaçáo de produtos e da criaçấo de empregos. A China encorajaria suas empresas a investir nessas zonas na África do Sul a fim de promover a industrialização e a melhoria em sua capacidade econômica. Os autores alertam, entretanto, que essas seriam "falsas promessas": as ZEEs manteriam práticas exploradoras e seriam cada vez mais informatizadas, dispensando o emprego de mão de obra intensiva, contrariando, portanto, a expectativa da criação de empregos (op. cit., p. 8-9).

Somente em 2008, a África do Sul estabeleceu, em certa medida, proteção aos trabalhadores dessas ZEEs. Segundo Thompson, Wet e Awaseh (2018), a aplicação de padróes de salário mínimo e a atuação de sindicatos não são proibidas, porém, em relatos obtidos pelos autores, os trabalhadores afirmaram que "pactos de trabalho" eram encorajados, burlando a regulação estabelecida. A Zona de Desenvolvimento Industrial Coega, situada desde 1999 na província de Eastern Cape, recebeu grandes investimentos da empresa BAIC. A promessa de empregos, entretanto, permaneceu não cumprida: em dezessete anos, somente 7.500 postos de trabalho permanentes foram criados no âmbito do empreendimento (op. cit., p. 9). Thompson, Wet e Awaseh (2018) destacam que a Zona Coega evidencia como os investimentos atraídos por ZEEs tendem a aumentar, cada vez mais, a exploração econômica.

\section{INVESTIMENTOS CHINESES NA ÍNDIA}

A Índia passou por uma crescente liberalização de sua economia desde os anos 1990, combinada com uma relativa estabilidade política. A linha liberal se fortaleceu quando Narendra Modi, do Partido Bharatiya Janata, assumiu o cargo

42. 0 texto do tratado está disponivel em: <https://investmentpolicy.unctad.org/international-investment-agreements/ treaty-files/3359/download>.

43. Para a discussão sobre os acordos de proteção de investimento do BRICS na África e as reformas na África do Sul, ver BRICS na África: mais do mesmo? Um estudo comparativo dos acordos de investimento do BRICS com países africanos, disponivel em: <http://www.pacs.org.br/files/2016/11/Publicao-Africa-BRICS-PT_BR.pdf>. 
de primeiro-ministro em 2014. Seu governo buscou incentivar investimentos em infraestrutura, como a construção de estradas, ferrovias e energia, e no desenvolvimento de "cidades inteligentes", favorecendo um ambiente de negócios aberto a investidores estrangeiros, incluindo os de origem chinesa (The Economist e Corporate Network, 2016, p. 71). É inevitável, entretanto, uma relativa concorrência entre as duas potências na região asiática.

As relaçôes entre a China e a Índia podem ser caracterizadas por uma combinação entre tensôes geopolíticas e um crescente interesse comercial (Patil, 2017). Em termos geopolíticos, o megaprojeto chinês Belt and Road Initiative (BRI) ${ }^{44}$ aumentou os tensionamentos ao estabelecer a rota do Corredor Econômico China-Paquistão, que atravessa o território da Caxemira, região de disputa e conflito entre os países fronteiriços. Tal cenário fez com que a Índia não participasse do fórum da BRI em Pequim e se ausentasse da reunião da Organização de Cooperação de Shangai em 2018. ${ }^{45}$ O ápice das tensôes entre os dois países ocorreu em 2017, com a disputa da regiấo de Doklam, no Butão pequeno país asiático aliado histórico da Índia -, que acusou a China de construir uma estrada em seu território, violando sua soberania. ${ }^{46}$ China e Índia chegaram a enviar suas tropas para a regiáo, arriscando chegar a um conflito militar.

Não obstante as tensóes e rivalidades geopolíticas, é possível evidenciar crescentes interesses econômicos e comerciais entre a China e a Índia. No que tange ao comércio, as transaçóes passaram de US $\$ 2,9$ bilhóes para US $\$ 71$ bilhóes entre 2000 e $2015,{ }^{47}$ entretanto a balança comercial indiana é deficitária ante a China. Enquanto a Índia exporta, essencialmente, matérias-primas e bens intermediários para a China, as exportaçóes chinesas para a Índia compreendem bens manufaturados, equipamentos de energia e produtos de telecomunicação. ${ }^{48}$ Quanto aos investimentos, os dados mostram uma tendência de crescimento: entre 2011 e 2016, o IED chinês na Índia passou do 35ํㅜ para o 17o lugar (Patil, 2017). Apesar disso, ele ainda é pequeno dentro do montante total: de US\$ 200 bilhões em investimentos recebidos pela Índia até 2016, somente US\$ 10 bilhōes eram de origem chinesa. Isso se dá pela falta de confiança entre os dois países e

44. 0 projeto chinês consiste em uma plataforma de cooperação econômica transnacional que toma forma em dois eixos: 0 terrestre, chamado cinturão, que vai da China até a Escandinávia; e o corredor marítimo, seguindo rotas comerciais. Essa iniciativa passa por cerca de setenta países na Ásia, na África e na Europa, englobando um terço do PIB mundial e $65 \%$ da população do planeta. Estima-se que um quarto de todos os bens e serviços do mundo irá passar por essa plataforma, promovendo investimentos maciços em transporte e energia, tais como pontes, gasodutos e ferrovias (Abdenur e Muggah, 2017).

45. Disponível em: <https://timesofindia.indiatimes.com/india/india-sticks-to-its-own-path-says-no-to-chinas-beltroad-initiative/articleshow/63903471.cms>.

46. Disponível em: <https://www.dw.com/pt-br/estrada-no-himalaia-coloca-china-e-\%C3\%ADndia-\%C3\%A0-beirade-conflito/a-39972873>.

47. Disponivel em: <https://sptnkne.ws/ehNe>.

48. Disponivel em: <https://anantacentre.in/reports/india-china-economic-ties-the-way-forward>. 
ocorre, em boa parte, impulsionado por pequenas e médias empresas chinesas, que buscaram oportunidades de mercado na Índia. ${ }^{49}$

De acordo com Patil (2017), os dados oficiais do governo indiano sobre o IED chinês entre 2000 e 2016 (que foi de US\$ 1,6 bilháo) estariam subestimados, uma vez que as estatísticas oficiais do governo indiano somariam somente os investimentos oriundos da China continental, deixando de fora os fluxos que vêm de Hong Kong ou de paraísos fiscais. Há maior concentração de investimentos na indústria automobilística, mas também crescente interesse no setor de eletrônicos e químicos. Uma das principais aquisições anunciadas é a compra da farmacêutica Gland Pharma pela Shanghai Fosun Pharmaceutical. Segundo Patil (2017), os custos da força de trabalho indiana seriam até três vezes mais baixos que os da China, o que representaria um atrativo ao investimento de multinacionais chinesas. Nos últimos anos, uma característica do investimento chinês na Índia foi o direcionamento para startups, principalmente ligadas ao e-commerce, chegando ao volume de cerca de US\$ 3,7 bilhóes entre 2015 e 2017 (Banerjee, 2018).

Segundo a UNCTAD (2017, p. 19), em 2015 e 2016, a empresa estatal chinesa CRRC Corporation investiu US\$ 53 milhóes em uma joint venture para produzir equipamentos de transporte ferroviário na Índia. Além disso, as multinacionais chinesas Alibaba, Xiaomi e Didi Chuxing também investiram na Índia, e a empresa chinesa OPPO, que atua nos setores de comunicação e tecnologia, também entrou no mercado indiano (op. cit., p. 55). Neste mesmo período, quatro marcas chinesas ficaram ranqueadas entre o segundo e o quinto lugar, somando juntas $46 \%$ do mercado indiano (idem, ibidem).

Um outro exemplo de destaque é a parceria envolvendo a empresa de Wang Jianlin, parte do Dalian Wanda Group, que atua majoritariamente no setor imobiliário e realizou dois acordos: o primeiro, de 2012, com o Reliance Group para a criação de uma startup a fim de desenvolver projetos no setor imobiliário (Ying, 2012); o segundo, de 2016, entre a empresa e o governo de Haryana, destinado à construção de cinco parques industriais temáticos e shopping centers. ${ }^{50} \mathrm{Os}$ investimentos chineses na Índia também se evidenciam no setor de infraestrutura e podem ser vistos em diversas áreas do país, objetivando a construção de novas infraestruturas para a produção e novas bases para as empresas. Muitos deles são resultado de acordos com o NDB do BRICS e com o Banco Asiático de Investimento em Infraestrutura (Asian Infrastructure Investment Bank - AIIB), que podemos considerar como investimento chinês indireto.

49. Disponivel em: <https://anantacentre.in/reports/india-china-economic-ties-the-way-forward>.

50. Disponível em: <https://economictimes.indiatimes.com/wealth/real-estate/equity-sharing-row-hits-dalian-wandasharyana-project/articleshow/58407493.cms>. 


\section{FIGURA 3}

Investimentos chineses na Índia

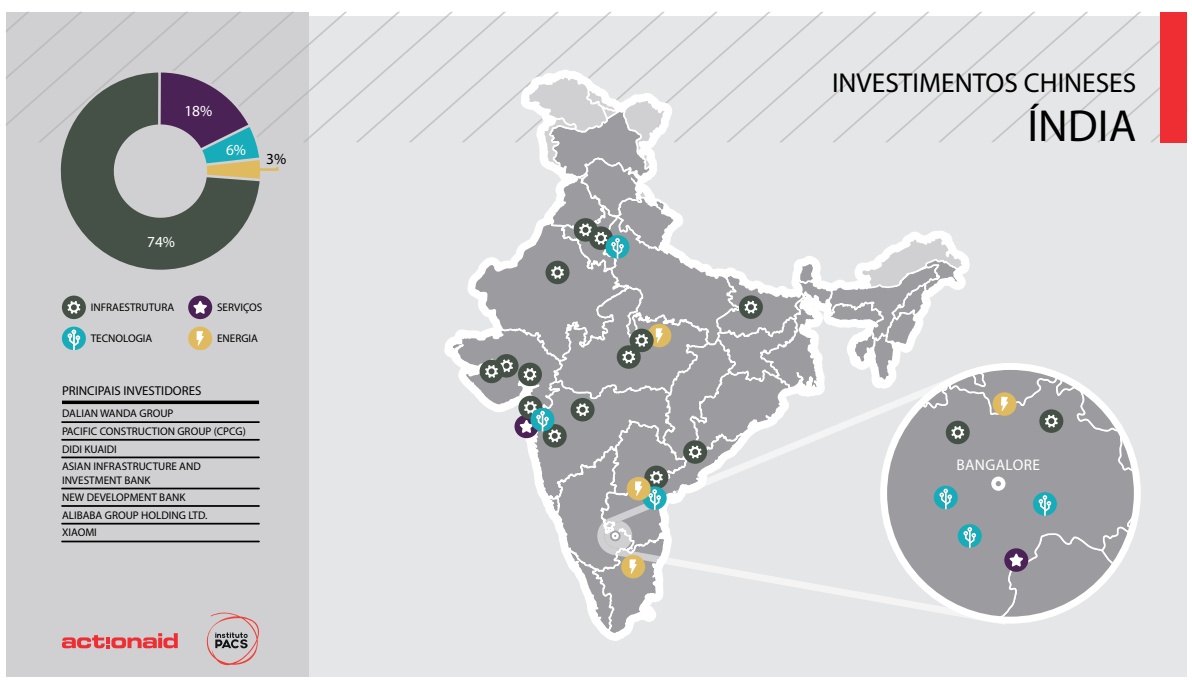

Fonte: Garcia (2018, p. 68-69).

Obs.: Figura cujos leiaute e textos não puderam ser padronizados e revisados em virtude das condições técnicas dos originais (nota do Editorial).

O NDB aprovou oito projetos na Índia entre 2016 e 2018, totalizando US\$ 2.550 milhóes em empréstimos (NDB, 2018a, p. 44). A grande maioria se destinou a projetos de transporte e infraestrutura (42\%), ao setor de irrigação e recursos hídricos (32\%), além de desenvolvimento urbano e energia limpa. Os principais receptores foram governos provinciais (como Madhyra Pradesh, Rajasthan e Bihar), além do Canara Bank. Recentemente, em 2019, o NDB aprovou mais dois projetos na área de transporte e infraestrutura: para o Departamento Assam de Obras Públicas (US\$ 300 milhóes); e para o Departamento de Obras e Estradas da província de Andhra Pradesh (aproximadamente US\$ 600 milhóes). ${ }^{51}$

Por sua vez, os desembolsos do AIIB se destinaram a quinze projetos entre 2016 e 2019, que se concentram no setor de energia e infraestrutura, por meio dos quais o banco contribui com uma parte do montante total do projeto. ${ }^{52}$ Segundo um relatório da revista (The Economist e Corporate Network, 2016, p. 66) a adesão da Índia ao AIIB, que é liderado pela China, mostra que, apesar das rivalidades no campo da segurança e da geopolítica, há abertura para maior atuação política e capacidade de barganha com o governo chinês, sobretudo considerando que a Índia é o segundo país com mais cotas de açóes no AIIB, somente atrás da própria China. 
A Índia empreendeu políticas públicas voltadas ao desenvolvimento industrial e à atração de investimento externo, como o chinês. Os dois principais programas foram o Make in India e o Invest India. ${ }^{53} \mathrm{O}$ primeiro é um programa do governo indiano lançado em 2014 com o objetivo de tornar o país um centro global de design e manufaturas. O programa tem onze áreas de concentração e 25 setores de foco específicos para os quais o governo liberalizou a política de IED, permitindo a rota automática ${ }^{54}$ de mais de $50 \%$ dos investimentos. Consequentemente, o fluxo de IED vem crescendo desde 2014, sendo maior no setor manufatureiro, com um aumento de 38\% em 2016-2017. Entre outras empresas globais que chegaram ao país nesse momento, a chinesa Shanghai Fosun Pharmaceutical criou joint ventures na Índia para comprar "ativos estressados". ${ }^{5}$.

A outra iniciativa, Invest India, ${ }^{56}$ é um programa para a promoçăo e a facilitação de investimentos, com a atuação de uma agência para a simplificação do ambiente de negócios. Almeja ser a referência para os investidores na Índia, disponibilizando especialistas formados em diferentes países e setores, que orientam as melhores entradas de mercado, oferecem análises sobre a indústria e localizam parceiros e advocacia política com os tomadores de decisão. Segundo Banerjee (2018), o programa pretende promover o país como o "melhor destino para investimentos", com uma lista de seiscentas companhias estrangeiras que planejam investir nos próximos cinco anos, além de outras duzentas companhias globais listadas, que ainda não atuam no país, a fim de aproximá-las - grande parte delas de origem chinesa.

China e Índia mantiveram um TBI entre 2006 e 2017, que confere garantias aos investidores de ambos os países, como o tratamento igualitário entre investidor nacional e estrangeiro e o princípio de nação mais favorecida. Apesar do término do tratado, as regras têm quinze anos de efeito residual e não há previsão de renovação ou nova elaboração do acordo. ${ }^{57}$ Por fim, é relevante mencionar o Diálogo Econômico Estratégico (Strategic Economic Dialogue - SED) China-Índia, iniciado em 2011, com rodadas anuais para estreitar as relaçóes econômicas. O SED é composto por grupos de trabalho em diferentes setores: energia, infraestrutura, meio ambiente e tecnologia. Havia a expectativa de que o SED aumentasse a presença de empresas

53. Não constam nos sites desses programas projetos realizados em cooperação com a China. Entretanto, segundo o site de notícias Sputnik News, a China aumentou os investimentos nesses programas em 2015. Disponível em: $<$ https://br.sputniknews.com/mundo/201509152130750/>.

54. A entrada de IED por não residentes na Índia é regulada por duas rotas: rota automática e rota de aprovação. A primeira é destinada a setores e níveis de investimento menos restritos. Já a segunda é regulada por agências governamentais que examinam o investimento estrangeiro enquanto o aprovam. Disponível em: <https://www. indianeconomy.net/splclassroom/what-is-automatic-route-and-approval-route-in-fdi/>.

55. Ativo estressado é como são chamados os ativos não rentáveis, os empréstimos reestruturados e ativos baixados (aqueles que o banco não conta o valor que o mutuário lhe deve e que serão compensados de outra forma). Disponível em: <https://www.indianeconomy.net/splclassroom/what-is-stressed-assets/>.

56. Disponivel em: <https://www.investindia.gov.in/about-us>.

57. Informações retiradas do TBI entre a China e a Índia. Disponível em: <https://investmentpolicy.unctad.org/ international-investment-agreements/treaty-files/742/download>. 
chinesas na Índia, ${ }^{58}$ mas ele foi além e estabeleceu diálogos específicos sobre defesa, segurança e finanças. Para Panda (2014), esse mecanismo reforçaria os espaços de cooperação já existentes - BRICS, G20 e iniciativas regionais, como a Parceria Econômica Regional Abrangente (Regional Comprehensive Economic Partnership - RCEP) - e precisaria solucionar problemas, como o deficit comercial entre Índia e China. Vale notar que, até 2012, a China mantinha esse tipo de diálogo somente com os Estados Unidos, além da Índia (Singh, 2012). ${ }^{59} \mathrm{O}$ último encontro ocorreu em 2018 e serviu para restabelecer a intenção de cooperação após as tensões geopolíticas em Doklam.

Concluímos que as relaçôes econômicas entre Índia e China se dão em um marco tênue entre cooperação e competição. Esta última não se dá somente no âmbito geopolítico, como apresentado no início, mas também no âmbito econômico, como duas potências emergentes de peso econômico na regiáo asiática. Diferentemente dos outros membros do BRICS - Brasil e África do Sul -, as negociaçóes entre China e Índia acontecem em uma estrutura relativamente mais horizontal de barganha. Ainda assim, com a inclinação mais liberal do governo Modi, o mercado da Índia tem oferecido grandes atrativos para a entrada de investidores chineses, muito embora a Índia venha crescentemente reivindicando, em contrapartida, mais abertura do mercado chinês para seus investidores. Impactos sociais e ambientais de projetos chineses na Índia não estão em evidência como em outros lugares, apesar de a Índia ser um país conhecido por conflitos ambientais, raciais e de gênero. ${ }^{60}$ É possível estimar que, especialmente em questôes trabalhistas, com salários rebaixados e regulação frouxa como no setor de serviços, os investimentos chineses podem acelerar uma corrida para baixo nos padrōes trabalhistas, que já são frágeis na Índia.

\section{CONCLUSÕES}

Neste trabalho, mostramos um panorama geral dos investimentos da China em outros três países do BRICS: Brasil, África do Sul e Índia. Em nossa leitura, o BRICS configura um marco do início do século XXI e gerou a expectativa de construção de uma ordem mundial diferenciada daquela baseada nos Estados Unidos como potência hegemônica. Consideremos, entretanto, que a capacidade real do BRICS de moldar uma nova ordem mundial com bases mais justas foi limitada. Mostramos que, apesar de ter construído, na última década, diferentes

58. Disponivel em: <https://www.hindustantimes.com/world/sino-india-dialogue-looking-at-investment/storyYr540sUaPNrnhNCXL91uAP.html>.

59. A Índia também mantém um acordo de SED com a Rússia. Disponível em: <https://economictimes.indiatimes. com/news/defence/indo-russian-economic-dialogue-in-july/articleshow/64314240.cms>. Por sua vez, China e Rússia deram início a um innovation dialogue, na área de defesa e ciência e tecnologia. Disponível em: <http://www.cistc. gov.cn/englishversion/News_Events/News_Events4.asp?column=133\&id=99598>.

60. Disponível em: <https://news.mongabay.com/2016/02/india-has-most-cases-of-social-and-environmentalconflict-according-to-environmental-justice-atlas/>. 
espaços de cooperação e instituições comuns, a relação entre os membros do BRICS é assimétrica, tendo em vista particularmente o peso econômico da China. Como uma potência econômica global, a China ascende em termos de comércio, investimentos, capacidade produtiva e tecnologia, expandindo-se para outros países e regióes do mundo, entre elas as regiốes historicamente exploradas no Sul Global: África, América Latina e Ásia.

A entrada de investimentos chineses no Brasil se acelerou a partir de 2010, concentrando-se especialmente no setor de energia, mas com expansão mais recente para outros segmentos, como agricultura. Apresentamos um conjunto de atores e mecanismos políticos e financeiros que apoiam essa expansão. $\mathrm{O}$ Brasil mantém um superavit comercial com a China, porém essas relaçóes comerciais reproduzem a clássica "divisão internacional do trabalho" entre a exportação de commodities dos setores primários (essencialmente grãos e minério) e a importação de manufaturados e semimanufaturados. As recentes mudanças políticas no Brasil, com o processo de impeachment de Dilma Rousseff em 2016 e a eleição de Jair Bolsonaro em 2018, geraram um quadro de incertezas com relação à posição do Brasil no BRICS e sua relação com a China. Percebe-se, contudo, que os setores do agronegócio e da mineração, que apoiaram esses processos políticos recentes, não podem prescindir do comércio e das relaçóes com a China e, por isso, contam com certo pragmatismo. A política de abertura dos setores estratégicos brasileiros para a entrada de empresas multinacionais (como no caso do petróleo) e os previstos programas de privatizaçóes de empresas e ativos públicos poderão acelerar ainda mais os investimentos chineses no Brasil, contraditoriamente à agenda de alinhamento aos Estados Unidos.

Por sua vez, a entrada de investimentos chineses na África começa na década anterior, a partir do início dos anos 2000, motivada pela busca por recursos naturais e energéticos, e conduzida majoritariamente, naquele momento, por grandes empresas estatais chinesas e apoiada por linhas de crédito específicas do CDB. Nesse processo, a África do Sul foi fundamental, tendo em vista sua estrutura econômica e política como uma potência regional. Não é por acaso que a maior aquisiçáo chinesa na África foi a do Standard Bank sul-africano, conforme mostramos. Atualmente, o quadro geral dos investimentos chineses no continente africano é mais diversificado: além dos setores de mineração e infraestrutura, investidores chineses já avançaram em finanças, varejo, telefonia e manufatura, como demonstramos no caso das ZEEs. Tudo isso vem sendo amplamente apoiado nos encontros do FOCAC, principal espaço de articulação entre investimentos, créditos e financiamento e ajuda chinesa para a África. Nesse sentido, a África do Sul continua sendo a "porta de entrada" para investidores chineses no continente, reforçando seu papel intermediário entre as grandes potências e as economias mais frágeis africanas. 
Tanto no Brasil quanto na África do Sul, os IEDs em setores relacionados a recursos naturais, energia e infraestrutura têm impactos sobre as populaçóes locais que vivem de seu trabalho nos territórios. São gerados questionamentos quanto ao próprio modelo de desenvolvimento que coloca o trabalho e a natureza como mercadorias para a acumulação de capital concentrada nas mãos de alguns poucos grupos econômicos voltados para o mercado externo. O modelo chinês de concessão de empréstimos financeiros por exportação de commodities (apontado na literatura como loans-for-oil) tende a reforçar esse mesmo modelo de desenvolvimento, gerando novas formas de endividamento entre países do Sul. Esse endividamento traz consigo uma forma indireta de condicionalidade, que é a estrutura das matrizes produtivas das economias africanas e latino-americanas condicionadas à produção e à exportação desses bens minerais e energéticos, dificultando as possibilidades de diversificação das matrizes produtivas para as futuras gerações.

O caso dos investimentos chineses na Índia revelou-se distinto dos casos do Brasil e da África do Sul. As relaçóes entre as duas potências asiáticas estão permeadas por tensóes geopolíticas, de um lado, e um crescente interesse econômico, de outro. O megaprojeto BRI, que envolve parceiros econômicos da Índia, bem como seus rivais históricos, como o Paquistão, gerou tensionamentos regionais evidentes entre os dois países. A Índia liberalizou sua economia nos últimos anos e abriu ainda mais seu mercado para a entrada de capital estrangeiro. Apontamos dois programas nacionais relevantes nesse aspecto, o Make in India e o Invest India, porém a entrada de empresas chinesas ainda é mais lenta. Elas se concentram no setor de infraestrutura, em alguns investimentos em startups tecnológicas e na indústria farmacêutica. Apesar disso, dois espaços recentes de aproximação entre China e Índia foram os dois novos bancos multilaterais criados com o peso econômico da China. Assim, o NDB e o AIIB têm sido mecanismos de entrada de capitais chineses em projetos na Índia.

\section{REFERÊNCIAS}

ABDENUR, A. E.; MUGGAH, R. A nova rota da seda e o Brasil. Le Monde Diplomatique Brasil, São Paulo, 12 jun. 2017. Disponível em: <http://diplomatique. org.br/a-nova-rota-da-seda-e-o-brasil/>. Acesso em: 2 ago. 2018.

AGUIAR, D. A geopolítica de infraestrutura da China na América do Sul: um estudo a partir do caso do Tapajós na Amazônia Brasileira. Rio de Janeiro: ActionAid; FASE, 2017.

AMORIM, F. Fundo Brasil-China de cooperação para expansão da capacidade produtiva e o financiamento de longo prazo no Brasil. Rio de Janeiro: Ibase, maio 2018. 
BANERJEE, N. China's investment in India. Millennium Post, New Delhi, 26 Feb. 2018. Disponível em: <http://www.millenniumpost.in/opinion/chinasinvestment-in-india-286998>. Acesso em: 17 jun. 2018.

BRICS BUSINESS COUNCIL. South African BRICS investment programmes. [s.l.]: BRICS Business Council, Oct. 2016. Disponível em:<http:// www.brics-info.org/wp-content/uploads/2016/11/BRICS-SA-guide-oninvestment-opportunities-FINAL-October-2016.pdf>. Acesso em: jun. 2020.

CEBC - CONSELHO EMPRESARIAL BRASIL-CHINA. Investimentos chineses no Brasil 2016. Rio de Janeiro: CEBC, maio 2017.

Investimentos chineses no Brasil 2018. O quadro brasileiro em perspectiva. Rio de Janeiro: CEBC, jul. 2019.

CEPAL - COMISSÃO ECONÔMICA PARA A AMÉRICA LATINA E O CARIBE. La inversión extranjera directa en América Latina y el Caribe. Santiago: CEPAL, 2017.

Explorando nuevos espacios de cooperación entre América Latina y el Caribe y China. Santiago: CEPAL, jan. 2018.

CHEN, W.; DOLLAR, D.; TANG, H. Why is China investing in Africa? Evidence from the firm level. [s.l.]: [s.n.], Aug. 2015. Disponível em: <https:// www.brookings.edu/wp-content/uploads/2016/06/Why-is-China-investing-inAfrica.pdf>. Acesso em: out. 2019.

CHERU, F.; OBI, C. Introduction. In: (Ed.). The rise of China and India in Africa: challenges, opportunities and critical interventions. London; New York: Zed Books, 2010.

CHINA-CELAC FORUM. Basic information about China-CELAC Forum. [s.l.]: Department of Latin America and the Caribbean; Ministry of Foreign Affairs of China, Apr. 2016. Disponível em <http://www.chinacelacforum.org/ eng/ltjj_1/P020161207421177845816.pdf>. Acesso em: jun. 2020.

COLOMBINI NETO, I. Dinâmica capitalista dos investimentos chineses no Brasil. Rio de Janeiro: ActionAid Brasil; Mott Foundation, 2016.

COSTA, F. K. S.; MENDONÇA, T. G. de. Evolução do comércio bilateral entre Brasil e China: análises das relações comerciais. Revista Economia e Desenvolvimento, v. 29, n. 2, jul./dez. 2017.

CRAVEIRO, L. O que esperar de um governo Bolsonaro em relação à China. Valor Econômico, São Paulo, 18 out. 2018.

D'SA, D.; BOND, P. New Development Bank should have consulted before lending corrupt Transnet. Pambazuka, 2018. 
ESCHER, F.; WILKINSON, J.; PEREIRA, P. R. F. Causas e implicaçóes dos investimentos chineses no agronegócio brasileiro. In: JAGUARIBE, A. (Org.). Direction of Chinese global investments: implications for Brazil. Brasília: FUNAG, 2018. p. 289-336.

GARCIA, A. S. (Coord.). Investimentos da China no Brasil, África do Sul e Índia: arranjos institucionais, atores e impactos. Rio de Janeiro: Instituto PACS; ActionAid Brasil, 2018.

HE, C.; ZHU, S. China's foreign direct investment into Africa. The state of African cities 2018: the geography of African investment. Nairobi: UN-Habitat, 2018.

JAGUARIBE, A. Characteristics and directions of China's global investment drive. In: . (Ed.). Directions of Chinese global investments. Implications for Brazil. Brasília: FUNAG, 2018.

JINPING, X. For a new era of China-SA friendship. Sunday Independent, 22 Jul. 2018.

LOPES, B.; NASCIMENTO, D.; VADELL, J. FOCAC: estratégia econômica e política de cooperação Sul-Sul sino-africana. Carta Internacional, v. 8, p. 81-99, jul./dez. 2013.

NDB - NEW DEVELOPMENT BANK. Annual report 2018: investing for impact. Shanghai: NDB, 2018a. Disponível em: <https://www.ndb.int/ndbannual-report-2018/>.Acesso em: jul. 2019.

. Press release. Shanghai: NDB, 2018b. Disponível em:<https://www. ndb.int/press_release/ndb-president-minister-foreign-affairs-brazil-sign-agreementhosting-banks-americas-regional-office-sao-paulo/>. Acesso em: out. 2019.

PANDA, J. India-China Strategic Economic Dialogue (SED): progress and prognosis. IDSA Issue Brief, Apr. 2014.

PATIL, R. China set to be India's fastest growing FDI partner; leaps from 35th to 17th spot in 5 years. First Post, 10 abr. 2017.

PECEQUILO, C.; JUNQUEIRA, E. Uma visão comparada das relaçóes Brasil-China: o Plano Decenal (2012) e o Plano de Ação Conjunta (2015). Mundorama, fev. 2016.

SHEN, X. Private Chinese investment in Africa: myths and realities. Washington: World Bank, Jan. 2013. (Working Paper, n. 6311).

SHOUJUN, C.; MIRANDA, O. C. Enquadrando a cooperação energética sino-brasileira: perspectivas chinesas. Revista Brasileira de Estratégia e Relaçóes Internacionais, v. 5, n. 10, jul./dez. 2016. 
SINGH, T. Sino-Indian strategic economic dialogue: an analysis. IPCS Issue Brief, n. 184, Mar. 2012.

THE ECONOMIST; CORPORATE NETWORK. “One belt, one road”: an economic roadmap. [s.l.]: The Economist Corporate Network, 2016.

THOMPSON, L.; WET, P.; AWASEH, F. China's 'inclusive,' 'centripetal' investment - or super-exploitation? In: BRICS politricks: new subimperial power plays. [s.l.]: [s.n.], 2018. p. 200-205.

UNCTAD - UNITED NATIONS CONFERENCE ON TRADE AND DEVELOPMENT. World international report 2017: investment and the digital economy. Geneva: United Nations, 2017.

World investment report 2019: special economic zones. Geneva: United Nations, 2019.

VADELL, J. A. El Foro China-CELAC y el nuevo regionalismo para un mundo multipolar: desafíos para La Cooperación 'Sur-Sur'. Carta Internacional, v. 13, n. 1, p. 6-37, 2018.

YING, W. Wanda to tap Indian market. China Daily, 15 Dec. 2012.

\section{BIBLIOGRAFIA COMPLEMENTAR}

CEBC - CONSELHO EMPRESARIAL BRASIL-CHINA. Plano de Açáo Conjunta entre o governo da República Federativa do Brasil e o governo da República Popular da China (2010-2014). Rio de Janeiro: CEBC, 2010. Disponível em: <http://www.cebc.com.br/sites/default/files/plano_de_acao_ conjunta_2010_-_2014_2_.pdf>. Acesso em: 24 jul. 2018. 